to prazosin having a potentiating effect on the other antihypertensive drugs also being employed at the same time. Clearly this aspect requires further study.-I am, etc.,

Department of Medicine Charing Cross Hospital (Fulham), London $\mathbf{W} .6$

\section{Hernias in Children}

SIR,-I have read with interest your leading article on the above subject ( 31 August, $p$. 540 ), and though only an "ordinary" general and not a paediatric surgeon I would like to make three points. These may not be altogether out of place as the majority of hernias in neonates probably reach general and not special hospitals.

Firstly, I cannot agree that spontaneous disappearance never occurs. Over the years I have seen several intermittent neonatal hernias which have ceased to appear after a few months. One has to make up one's mind either to take the very small risk of strangulation occurring or, on the other hand, of doing a possibly unnecessary operation. My own practice for many years has been to leave those hernias which occur only intermittently and to operate on those which are down most of the time. I see the former ones at monthly intervals, and if there is no improvement after 3-4 months will then treat them surgically. I have never yet had one "strangulate on me."

My second point concerns the treatment of the possible contralateral hernia. Some years ago I tried enthusiastically in several cases to demonstrate the other sac with a curved director but was totally unsuccessful. Perhaps I was over-cautious. I now feel that searching for a sac which may not be there, and even if it is may not cause symptoms for many years, is really not justified. After all, this operation is not entirely without complications and one does not want to prolong it unnecessarily.

My third and last point is a plea to my fellow consultants. In experienced hands removing a hernial sac in a tiny baby is the simplest of operations, taking only 10-15 minutes. The inexperienced can get hopelessly lost, especially where "puppy fat" is excessive. My plea, therefore, is that never, never should this operation be delegated to a house surgeon or inexperienced registrar unless competent supervision is immediately available.-I am, etc.,

ROBIN BURKITT

Ashford Hospital,
Ashford, Middlesex

\section{Age Dependence of T-Cells}

SIR,-In 1967 we reported ${ }^{1}$ our finding that the mitotic activity of peripheral lymphocytes was lower in children under 2 years of age than in adults. Since then spontaneous rosette formation on incubation with sheep erythrocytes has been found to occur with lymphocytes derived from the thymus ( $T$ cells). ${ }^{2}{ }^{3}$ We therefore used this technique in a further study of cellular immunity in infants.

The number of rosettes formed from at least 300 lymphocytes was counted in 1971 healthy children and adults. The results (see table) were expressed as the number of

Number of Rosettes formed by T-Cells in 171 Healthy Children and Adults

\begin{tabular}{|c|c|c|c|c|c|}
\hline \multirow{2}{*}{ Age } & \multirow{2}{*}{$\begin{array}{l}\text { No. of } \\
\text { Children }\end{array}$} & \multicolumn{2}{|c|}{ Rosettes/100 Lymphocytes } & \multicolumn{2}{|c|}{ Rosettes $/ \mathrm{mm}^{3}$ Peripheral Blood } \\
\hline & & Mean & Range & Mean & Range \\
\hline 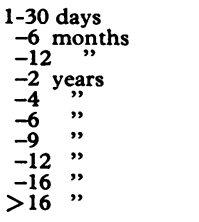 & $\begin{array}{l}10 \\
11 \\
15 \\
14 \\
16 \\
15 \\
21 \\
14 \\
15 \\
40\end{array}$ & $\begin{array}{r}1.9 \\
3.9 \\
9.9 \\
16.0 \\
20.0 \\
24.0 \\
29.0 \\
32.0 \\
32.0 \\
40.0\end{array}$ & $\begin{array}{r}1-4 \cdot 5 \\
1-10 \\
4-20 \\
9-26 \\
10-48 \\
16-43 \\
14-62 \\
20-60 \\
19-59 \\
21-77\end{array}$ & $\begin{array}{r}88 \\
243 \\
618 \\
792 \\
988 \\
1,036 \\
953 \\
978 \\
1,110 \\
1,124\end{array}$ & $\begin{array}{c}13-273 \\
56-600 \\
123-1,044 \\
528-1,056 \\
491-1,452 \\
490-1,513 \\
468-1,520 \\
483-1,499 \\
624-1,526 \\
517-1,776\end{array}$ \\
\hline
\end{tabular}

rosettes per 100 lymphocytes as well as the absolute number of rosettes $/ \mathrm{mm}^{3}$ of peripheral blood. The number of rosettes in creased gradually with age to reach about adult levels at 2 years if expressed per 100 lymphocytes or at 12 months if expressed as number $/ \mathrm{mm}^{3}$ of peripheral blood. This discrepancy is due to the relative decrease of lymphocytes $/ \mathrm{mm}^{3}$ after 12 months of age.

The increase of rosette formation with age during infancy is better illustrated by plotting the regression line which represents the age dependence of the total number of rosettes $/ \mathrm{mm}^{3}$ of peripheral blood (fig.). The inclination factor $(\beta=690)$ is significantly high. It shows that the increase in the number of rosettes during the first year of life is about 50 per month, and $P<0.001$ makes this finding statistically highly significant. On the other hand, the increase during the second year of life is 10 times smaller, which is not significant.

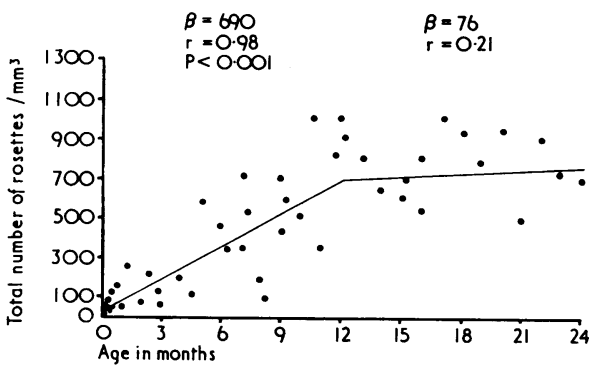

These findings show that T-cells, as identified by their formation of rosettes with sheep erythrocytes, are few at birth and slowly and steadily increase in number each month until they reach about adult levels at 1 year of age.-We are, etc.

N. Matsaniotis

C. MANTALENAKI-ASFI

M. APOSTOLOU

P. LIAKOPOULOU

Athens University

Department of Pediatrics

t. Sophie's Children's Hospital, 1 Matsaniotis, N., Economou-Mavrou, C., and $1967,42,549$.

2 Jondal, M.. Holm, G., and Wigzell, H., foumal of Experimental Medicine, 1972, 136, 207. foumal of Wybran, J., Carr, M. C., and Fudenberg, H. H.,
fournal of Clinical Investigation, 1972, 51, 2537.

\section{Saudi Arabian Medical School}

SIR,-Our next-door neighbour in Riyadh has several daughters, three of whom are married. We have no social relations with this family other than an occasional visit to my wife made by the youngest of these three girls, who is perhaps now in her late teens. She has a small child, but she remains in full-time education as the corporate family looks after the child while she attends classes. I have never met the girl, as custom dictates that such visits are made when I am out of the house, but my wife inquired on one occasion of the girl's views on the difficulty of continuing to gain an education at the same time as being a wife and mother. The reply was that she considered herself fortunate; she had been born young enough to have routine access to education, and marriage was a minor handicap. Her elder sisters had been less lucky; at every step they had been in the first cohort of female education, so that when they became due for secondary school they had to await the completion of the buildings and curricula. Likewise their entry into university had been delayed for the same reasons.

I was reminded of this girl when I read the letter from Dr. Susan Barlow (17 August, p. 473). I have no connexion with the University of Riyadh, but I have lived in Saudi Arabia for the past six years. During that time I have seen enormous progress, but progress taken at a rate that is acceptable to a society which, until a few years ago, had maintained an unchanged pattern of life for centuries. That pattern still imposes many restrictions upon social behaviour, but it also still guarantees that the elderly and infirm are cared for by their family and that theft and violent crime remain at levels almost unknown elsewhere in the world.

There are so fow areas today where British help is actively sought, and we should be proud that London University is held in such esteem that its guidance is behind the development of Riyadh's medical school. Of course there are female doctors in Saudi Arabia, and in due course there will be female leoturers too. It is not for us to stipulate when that should be, but $\mathrm{Dr}$. Barlow might reflect on the spirit that drives girls such as our neighbour to overcome obstacles that have never blocked her own path.-I am, etc.,

Riyadh,

R. A. JOHNSON

Saudi Arabi

\section{Women in Medicine}

SIR,-In your leading article $(7$ September, p. 590) you state that "those [women] who opt for two careers cannot normally expect to reach the highest points in medicine. They must be satisfied with achieving less in medicine than they would have done had they foregone marriage and family and devoted themselves to medicine full time."

Sir, I am astonished. Is fatherhood less important than motherhood in family life? I do not think so, but we do not judge the quality of a father by how much time he spends physically at home; nor do we 